\title{
Groundwater Resource in the Crystalline Rocks of the Johannesburg Area, South Africa
}

\author{
Tamiru A. Abiye ${ }^{1^{*}}$, Haile Mengistu ${ }^{2}$, Molla B. Demlie ${ }^{3}$ \\ ${ }^{1}$ School of Geosciences, University of the Witwatersrand, Johannesburg, South Africa \\ ${ }^{2}$ Council for Geosciences, Pretoria, South Africa \\ ${ }^{3}$ School of Geological Sciences, University of the Kwazulu-Natal, Durban, South Africa \\ Email: tamiru.abiye@wits.ac.za \\ Received December 10, 2010; revised January 20, 2011; accepted March 4, 2011
}

\begin{abstract}
Understanding the groundwater dynamics is very important for strategic management of the water resource as urbanization and population growth put South Africa's current water supply under tremendous stress. The groundwater resources potential and quality characteristics of the greater Johannesburg area, was thoroughly assessed using hydrogeochemical and environmental isotope techniques. The results of the geochemical and stable isotope investigations help understand the groundwater setting. Mixing process of fresh and polluted water is taking place at shallow zones within the weathered crystalline rocks and dissolution cavities in dolomites, where the rocks are characterized by the lithological and structural complexities. Furthermore, it was confirmed that the solute composition of the water results from two basic contributions: the reaction of meteoric water with weathered zones in the near surface area and direct infiltration through dolomite dissolution cavities. The results further indicate that the dominant movement mechanism of ions is through a diffusive process, which could be due to the limited availability of fractures with depth and its possible sealing by calcite precipitation. Consequently, the provenance of groundwater circulation is limited to shallow depths, however, dissolution cavities, fractured and sheared zones allow deeper circulation of groundwater. Moreover, the natural water quality is found to be highly impacted by acid mine drainage which is derived from the gold mines in the Witwatersrand basin as it has been observed in previous studies.
\end{abstract}

Keywords: Crystalline Aquifer, Diffusive Circulation, Dissolution Cavities, Johannesburg, Water Supply

\section{Introduction}

Most countries, located within the arid and semi arid regions like South Africa, are categorized as water stressed $[1,2]$ and depend primarily on groundwater as water supply for various developmental activities. Due to large water usage, the main water supply for big cities like Johannesburg and Pretoria is derived from surface water sources. However, many rural communities rely on groundwater for domestic supply, which is obtained from shallow aquifers composed of alluvials and weathered crystalline rocks. Groundwater also plays strategic role in supplying water for large irrigation fields in the area which is extracted from deep wells located within the dolomitic aquifer in the Transvaal Supergroup [3-5]. Therefore, understanding the nature of groundwater circulation and hydrogeochemical characteristics of the aquifers is crucial for sustainable development of the coun- try's water resources. Previous knowledge on the groundwater circulation media, natural quality of water could give insight on the state of pollution, which are generated from urban, irrigation, mining and industrial activities.

Figure 1 illustrates location of the study area which is characterized by semi arid climate with the mean annual rainfall ranging from 600 to $700 \mathrm{~mm} /$ year [6], showing high variability with the majority of rain falling during summer months (December through February). The summer rainfall in the area is extremely important in its contribution for groundwater recharge.

Due to the presence of complex and heterogeneous crystalline aquifers in the Johannesburg area, the identification of productive aquifers has become problematic and recharge is presumed to be small due to the crystalline nature of the rocks. Past studies clearly show that major ions and environmental isotopes are proven to be 
important in determining the characteristics of groundwater in complex aquifer systems [7]. The integrated application of the methods has also been successfully used in the characterization of the geochemical evolution in granitic batholiths in Canada and other parts of the world [7-9]. Because of the spatial variability in the degree of fracturing and weathering in the crystalline rocks, the development of water bearing horizons is limited to shallow weathering zones and fracture media. On the other hand, the dolomitic aquifers are identified as highly productive aquifers in the region $[5,10]$.

The study area and the adjoining Witwatersrand basin are well known for its large-scale urbanization and industrial activities with substantial water demand. The region hosts one of the world's largest gold and uranium mining basins having more than 120 mines. In the mining areas, deeper groundwater was pumped out at large scale with a rate of 110 Mega liters per day (ML/day) until 2008 to make underground mining possible [11]. However, evidences confirm that the deep underground mine pumping does not tremendously affect the shallow groundwater. Surface discharge of largely polluted pumped water to dams, reservoirs and local streams considerably increase recharge of the shallow aquifer [12].

According to [13] the Cradle of Human Kind World Heritage site which is located in the western part of Johannesburg is seriously threatened by the acid mine drainage. Ground and airborne geophysical surveys have also identified sub surface acid mine drainage pathways in Krugersdorp Game Reserve area [14]. Recent estimates of the rate of decant ranges between $18 \mathrm{ML} / \mathrm{d}$ and $36 \mathrm{ML} /$ day with a $\mathrm{pH} \approx 3$ and electrical conductivity of $\approx$ $550 \mathrm{mS} / \mathrm{m} \mathrm{[15].} \mathrm{In} \mathrm{the} \mathrm{area,} \mathrm{groundwater} \mathrm{is} \mathrm{highly} \mathrm{used}$ for domestic and industrial activities. With growing fresh water scarcity; groundwater resource assumes increasing importance and needs protection according to best management practice. Hence, it is important to understand the groundwater recharge and circulation mechanisms and quality in these crystalline rocks. Proper understanding of the geochemical process will further help in managing the groundwater quality in the region.

The elevation in the area ranges from 1365 meters above sea level (m a.s.l.) at Pretoria to $1753 \mathrm{~m}$ a.s.l. at Johannesburg (with an elevation difference of $388 \mathrm{~m}$ ). The central section of the city of Johannesburg is situated on the major water divide between the northern Limpopo River basin with numerous networks of tributaries and the southern Orange River basin (see Figure 1).

For this work, hydrogeochemical and isotope variables were considered as they give important indications regarding the geoenvironmental history of the enclosing rocks, the velocity and direction of movement and the mechanism of flow in the aquifers. The spatial variation in the concentration of dissolved substances determines the chemical properties and evolution of water along a flow path. In the study area, which is covered with large variety of basement lithologies, the large variation in water chemistry reflects the degree of fracturing and weathering of the host rocks.

\section{Objectives and Methods}

The main purpose of this work is to assess the quality variation, aquifer characteristics and hydrogeochemical nature of groundwater within the basement crystalline rocks of Johannesburg area. In order to understand the groundwater dynamics, groundwater database from the Department of Water and Environmental Affairs (DWEA), Pretoria, has been utilized with field verification on accessible water points for physical parameters such as $\mathrm{pH}$, Electrical Conductivity (EC) and Total Dissolved Solids (TDS). Additional samples were collected in 2009 and 2010 from western part of Johannesburg for environmental isotope analysis. Field visits were conducted in order to understand the lithostratigraphic relationship which helped for the preparation of the simplified geological map. There is an ongoing surface and ground water interaction project in the area and this paper reports the first results.

\section{Geological Framework}

The Johannesburg area is composed of crystalline rocks of Archean age. They are broadly classified as granitic rocks, meta-sedimentary and meta-volcanics (Figure 2). The Johannesburg dome which is located between Johannesburg and Pretoria which is circular in outline consists of Archean greenstones remnants (c. $3.34 \mathrm{Ga}$, [16] and intruded by tonalite, granodiorite, granite and migmatites, unconformably overlain by metasedimentary rocks of $<3000 \mathrm{Ma}$ [17-19]. The tonalites are the oldest rock types, migmatites are intermediate in age and granodiorite and granite are the youngest [19]. The oldest granitic rocks comprise a suite of tonalitic and trondjemitic gneisses and migmatites that occupy most of the northern half of the dome. Exposure of similar rocks also occurs on the southern edge of the dome and unconformably underlies the Witwatersrand Supergroup [19], [20].

The Witwatersrand basin is an arcuate structural basin lying within the Kaapvaal Craton. The Witwatersrand Supergroup is divided into the Lower West Rand Group and the upper Central Rand Group. The former conformably overlies volcanics of the Dominion Group and non-conformably overlaps Archean basement rocks of the Kaapvaal Craton. The south-central portion consists 


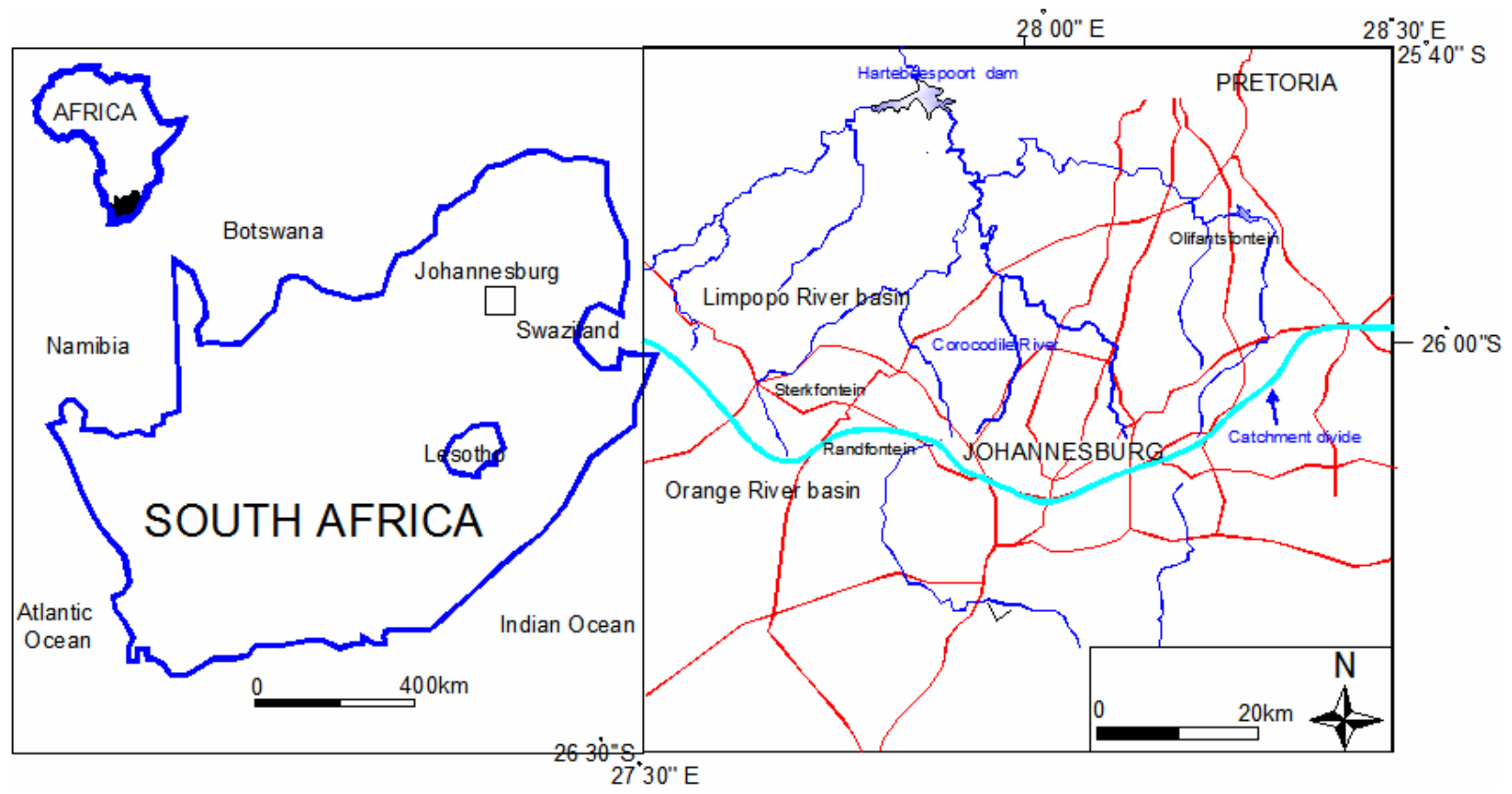

Figure 1. Location map of the study area, Johannesburg at the north central part of the country (east-west solid line is water divide between Limpopo and Orange Rivers, blue lines represent streams and red lines represent roads).

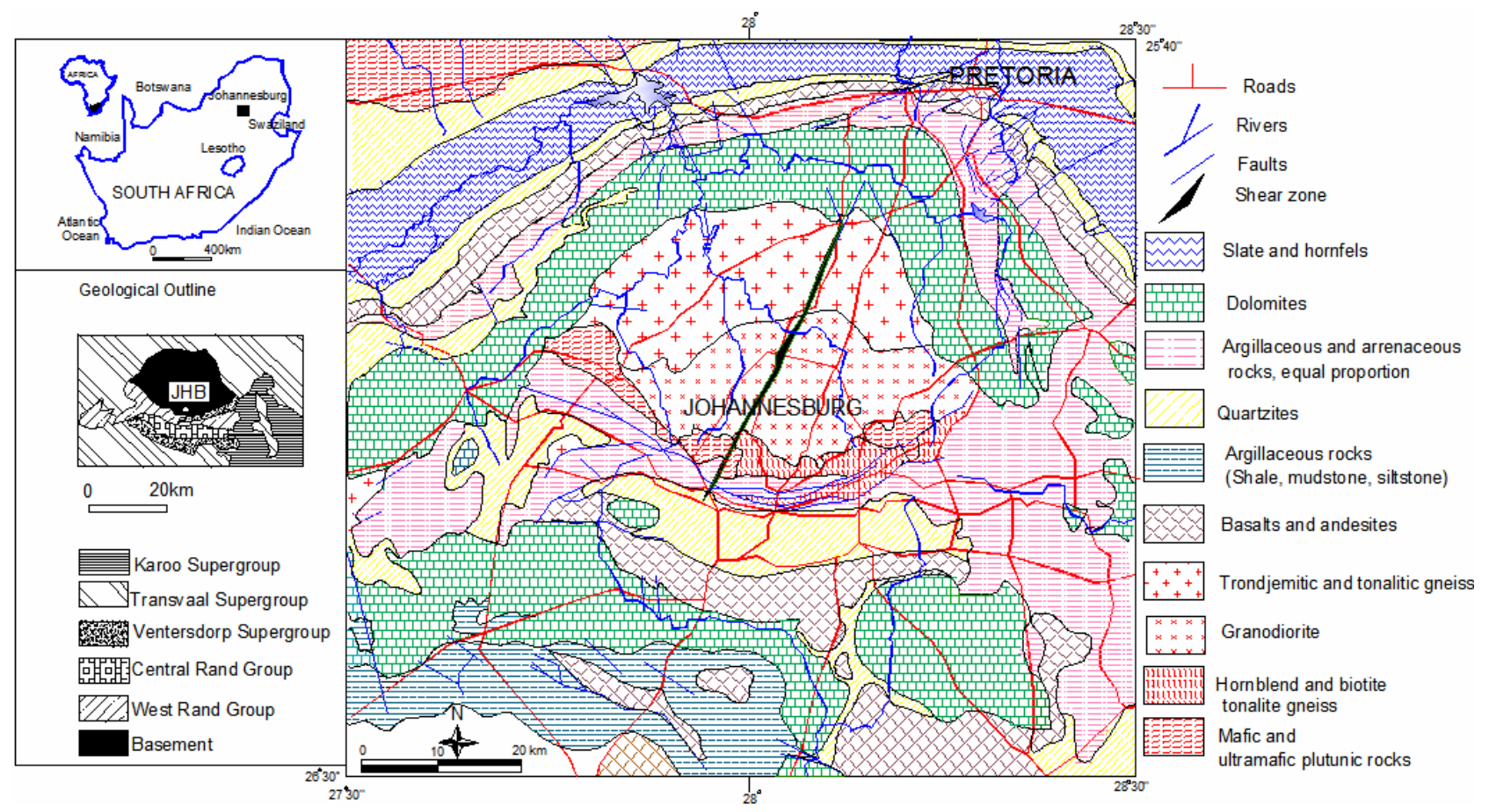

Figure 2. Simplified geological map of the Johannesburg area (Compiled from [17,25,27]).

mainly of a variety of homogeneous, medium grained granodioritic rocks. Locally, all rocks contain a gneissic fabric and are less developed in the granodiorite and the tonalities. The Witwatersrand Supergroup unconformably overlies basement granitoids and greenstones, as well as sedimentary and volcanic rocks of the Dominion
Group. It is made of thick terrigenous sequence comprising arenaceous and argillaceous sedimentary rocks. The deposition took place between 3074 and $2714 \mathrm{Ma}$ [21]. The part of Witwatersrand basin that lies close to Johannesburg dome is grouped under West Rand, Central Rand and East Rand Groups. The west rand group con- 
sists primarily of quartzites and shales. The Central Rand Group consists of different proportion of quartzites and shales where the sequence consists mainly of quartzites and conglomerates [22].

The Early Proterozoic Transvaal Supergroup comprises of relatively undeformed, unmetamorphosed volcanic rocks, quartzites, shales, dolomites iron formations, conglomerates and diamictites [23]. The Transvaal Supergroup is made of relatively undeformed, unmetamorphosed volcanic rocks, quartzites, shales, dolomites, iron formations, conglomerates and diamicites [23]. The Supergroup includes dolomites and iron formations of Chuniespoort Group [23] which is overlain by Pretoria Group that comprises of predominant mud rocks alternating with quartzitic sandstones, significant interbedded basaltic-andesitic lavas and subordinate conglomerates, diamictites and carbonate rocks all of which have been subjected to low grade metamorphism [24].

\section{Hydrogeological Framework}

The present landscape of the study area, which is marked by elongated ridges, rolling topography and wide plain areas could be a clear reflection of the old geological activity (intrusion, sedimentation, metamorphism, ductile and brittle tectonics) and subsequent erosion processes. These activities have tremendous impact on hydrogeological characteristics of the rocks primarily by regulating recharge into the groundwater. The Johannesburg dome, having a circular outline, form slopping relief terrain whereas the enclosing younger rocks (Transvaal Sequence) form relatively high ground. Fractures of all orientation and weathering zones exist in all rocks. From hydrogeological point of view, the rocks that outcrop in the study area fall under hardrock category with low groundwater productivity except dolomites that contain dissolution cavities and consequently host huge quantity of groundwater.

According to the Johannesburg hydrogeological map of 1: 500000 scale [25], and explanatory note [10]; four aquifer types have been identified in the area. Namely:

- An intergranular aquifer in the alluvial covered zones

- $\quad$ Fractured aquifer in the Witwatersrand Supergroup associated with fractures, fissures and joints

- The karstic aquifer in the dolomites

- The intergranular and fractured aquifer in the crystalline rocks

However, from detailed field surveys, it was possible to conceptualize that groundwater occurrence in the area can be categorized into three broad groups: near surface occurrence within the weathered profile; occurrence within fractures, dykes and shear zones; and occurrence within dissolution cavities in the dolomites. The main characteristic features of groundwater in the highly productive dolomitic aquifer [3-5] are pockets of conduits which are compartmentalized primarily by structural discontinuities such as left lateral strike slip faults. The dolomitic formations generate little surface run-off, suggesting relatively high recharge and predominance of underground water flow, which eventually drains to springs typically associated with dykes, faults or formation contacts [13]. However, it has been observed that dikes, sills and quartz veins generate local perched system which frequently generates springs in the area. The presence of recharging meteoric water through dykes and faults and the influx of thermal water along fractures within the deep gold mines in the Witwatersrand basin have been documented [26]. Therefore, occasionally dykes and faults play important role in regulating recharge and, channeled and deep groundwater circulation zones in the area.

The semicircular deformation of the Witwatersrand and Transvaal Supergroup rocks around Archean granitic pluton (see the central part in Figure 2) could play substantial role in regulating groundwater circulation in the area. In the same area, the randomly oriented left lateral strike slip faults with minor occurrence of right lateral strike slip faults with the associated weathered and sheared zones can potentially act as a conduit for accelerated groundwater flow. Since dikes constitute an important structural set up of the crystalline rocks in the area, they act as conduits for groundwater circulation besides compartmentalizing role in some instances. Owing to the fact that the area is made of deformed crystalline rocks, the main hydrostructures are represented mainly by fractures and weathered zones. The fractured Black Reef quartzites of the Witwatersrand Group that form the water divide between the northern Limpopo River basin and the southern Orange River basin are intensively fractured, which provide suitable media for vertical recharge. Granitic gneisses and quartizites, instead, are characterized by massive structures with wide fracture network while shales contain very tight fractures along inclined beds to the south. The conceptual model demonstrates that the city of Johannesburg is located on the water divide where groundwater flows away towards north and South (Figure 3). However, the hydraulic connection exists between different lithological units. The Transvaal dolomites in the western and eastern part of Johannesburg area, groundwater moves across the water divide through dissolution cavities and tectonic lineaments (Figure 2). Alluvial deposits found along several stream valleys in the area are highly productive, such as aquifers in the the lower Crocodile River valley (down-stream of Hartebeespoort dam), with 


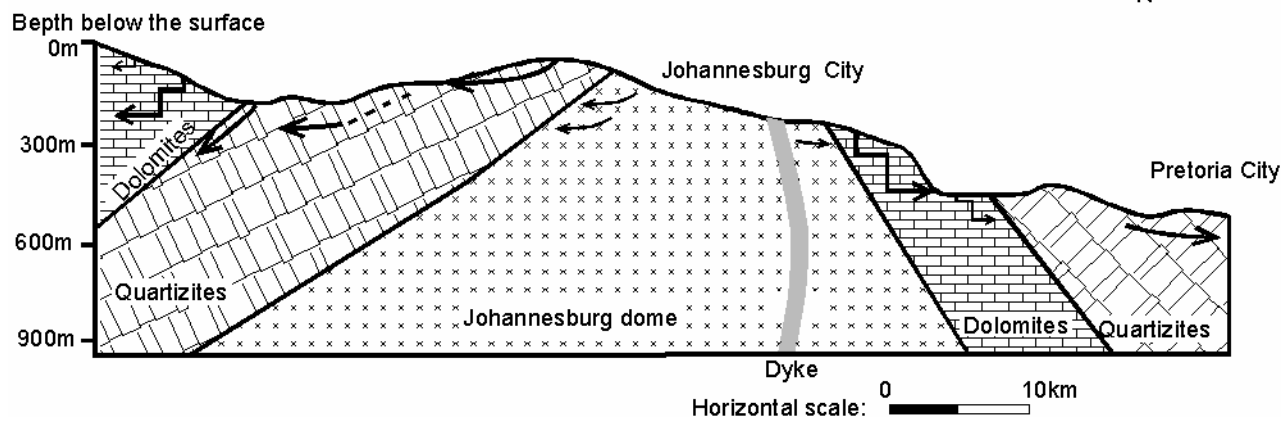

Figure 3. Conceptual hydrogeological model along south-north section in Johannesburg.

Table 1. Chemical composition of some water supply wells in the Johannesburg area.

\begin{tabular}{|c|c|c|c|c|c|c|c|c|c|c|c|c|c|c|}
\hline Code & Latitude & $\begin{array}{l}\text { Longit- } \\
\text { ude }\end{array}$ & $\begin{array}{l}\text { Eleve. } \\
\text { m.a.s.I }\end{array}$ & $\begin{array}{c}\text { SWL } \\
\text { (m) }\end{array}$ & $\begin{array}{c}\text { Well } \\
\text { Depth } \\
\text { (m) }\end{array}$ & $\mathbf{p H}$ & $\begin{array}{c}\mathbf{E C} \\
\mathbf{m S} / \mathbf{c} \\
\mathbf{m}\end{array}$ & $\underset{\mathrm{mg} / \mathrm{l}}{\mathrm{K}}$ & $\begin{array}{c}\mathrm{Na} \\
\mathrm{mg} / \mathrm{l}\end{array}$ & $\underset{\mathrm{mg} / \mathrm{l}}{\mathrm{Ca}}$ & $\begin{array}{c}\mathrm{Mg} \\
\mathrm{mg} / \mathrm{l}\end{array}$ & $\underset{\mathrm{mg} / \mathrm{l}}{\mathrm{Cl}}$ & $\begin{array}{l}\text { TAL } \\
\text { mg/l }\end{array}$ & $\begin{array}{l}\mathrm{SO}_{4} \\
\mathrm{mg} / \mathrm{l}\end{array}$ \\
\hline Well_1 & -26.03612 & 27.7 & 1520 & 7.92 & 9.14 & 7.7 & 112.5 & 1.36 & 62.5 & 93.3 & 53.3 & 94.3 & 97.6 & 227.1 \\
\hline Well_2 & -25.85639 & 28.16695 & 1430 & 15 & 31 & 7.6 & 66 & 1.63 & 6.8 & 69.6 & 38.9 & 15.4 & 263.3 & 20.4 \\
\hline Well_3 & -25.89639 & 28.3125 & 1487.83 & 22 & 38 & 7.7 & 53.9 & 0.54 & 16.1 & 45.4 & 31.1 & 20 & 172.4 & 32.1 \\
\hline Well_4 & -25.9275 & 28.21945 & 1480 & 30 & 45 & 7.28 & 87.6 & 1.76 & 61.3 & 63.6 & 30.1 & 78.2 & 209.7 & 59.1 \\
\hline Well_5 & -26.0174 & 27.71136 & 1463.52 & 30 & 56 & 7.2 & 98 & 1.51 & 46.1 & 87.8 & 49.1 & 70.2 & 119.8 & 229.7 \\
\hline Well_6 & -26.08056 & 27.57639 & 1545.22 & 53 & 60 & 6.8 & 83 & 0.7 & 1 & 7.1 & 4 & 1.5 & 42.4 & 9.9 \\
\hline Well_7 & -25.89862 & 28.30278 & 1519.46 & 67 & 69 & 7.4 & 37.1 & 1.38 & 5.8 & 35.2 & 20.6 & 6.6 & 121.3 & 21.6 \\
\hline Well_8 & -25.96945 & 28.28056 & 1586.23 & 76 & 83 & 7.75 & 40.1 & 0.43 & 4.9 & 39.4 & 23.9 & 6.4 & 168.8 & 11.4 \\
\hline Well_9 & -25.91689 & 28.33856 & 1500 & 10 & 87 & 7.85 & 24.6 & 0.15 & 1 & 23.8 & 12.8 & 1.5 & 118.7 & 5.5 \\
\hline Well_10 & -25.88916 & 28.20888 & 1460 & 40 & 89 & 7.4 & 56 & 0.92 & 9.3 & 46 & 37.7 & 18.1 & 224.2 & 7 \\
\hline Well_11 & -25.89222 & 28.32195 & 1524.21 & 63 & 92 & 7.58 & 255 & 0.62 & 5.6 & 24.2 & 15 & 4.6 & 92.3 & 8.1 \\
\hline Well_12 & -26.06825 & 27.64736 & 1573.01 & 92 & 98 & 7.64 & 373 & 0.54 & 14.2 & 30.5 & 19.8 & 26 & 115.2 & 15.8 \\
\hline Well_13 & -26.0508 & 27.67248 & 1546.77 & 74 & 108.5 & 7.66 & 34.4 & 1.6 & 7.6 & 35.1 & 21.2 & 39 & 98.5 & 47.3 \\
\hline Well_13 & -25.88222 & 28.25666 & 1460 & 107 & 114 & 7.2 & 44.8 & 0.65 & 11 & 41.4 & 25.9 & 11 & 192.5 & 12.6 \\
\hline Well_14 & -26.01667 & 28.28555 & 1570 & 116 & 117 & 7.47 & 50.2 & 1.28 & 12.7 & 39.8 & 31.4 & 28.5 & 158.6 & 33 \\
\hline Well_15 & -25.90861 & 28.31695 & 1501.21 & 134 & 135 & 7.8 & 64 & 0.86 & 51 & 39.9 & 24.1 & 41.3 & 153.2 & 76.1 \\
\hline Well_16 & -26.04625 & 27.67872 & 1543.61 & 132 & 135 & 7.82 & 31.6 & 0.4 & 3.2 & 30.8 & 19.3 & 10.9 & 125.8 & 8.3 \\
\hline Well_17 & -25.85694 & 28.23333 & 1490 & 148 & 158 & 7.65 & 60.4 & 2.73 & 6.4 & 62.3 & 35 & 3 & 265.9 & 15.6 \\
\hline Well_18 & -25.94961 & 28.34194 & 1580 & 19 & 164 & 7.48 & 20.4 & 0.38 & 1 & 21.3 & 11 & 1.5 & 106 & 6 \\
\hline Well_19 & -25.95 & 28.26806 & 1559.77 & 169 & 176 & 7.7 & 36 & 0.79 & 5.4 & 36.1 & 21.6 & 4.2 & 157.3 & 9.8 \\
\hline
\end{tabular}

blow yield as much as $16 \mathrm{l} / \mathrm{s}$ [10]. The dolomite areas are traversed by impervious and semi-pervious syenite and diabase dykes, which divide these areas into separate groundwater compartments [14]. In the dolomitic aquifer, the occurrence of cavities varies from place to place which is based on the intercalations found in dolomites.

Such variability depends on different generation of dolomite (dolomite containing chert layers-Eccles Formation and those without chert-Frisco Formation), the availability of acidic infiltrating water, the amount of groundwater moving through the system and the degree of saturation with respect to calcite and dolomite. In large part of the area, dolomites have notorious reputation of developing sinkholes due to the formation of dissolution cavities [14]. The presence of acid mine drainage which is generated from the slime dams and abandoned shafts from gold mines have a tremendous potential to enhance dissolution of dolomites in the area. The occurrence of a series of dissolution cavities along tectonic lines is a characteristic feature in the dolomites. Appearance and disappearance of springs is also a common feature in the area, which is controlled by availability 


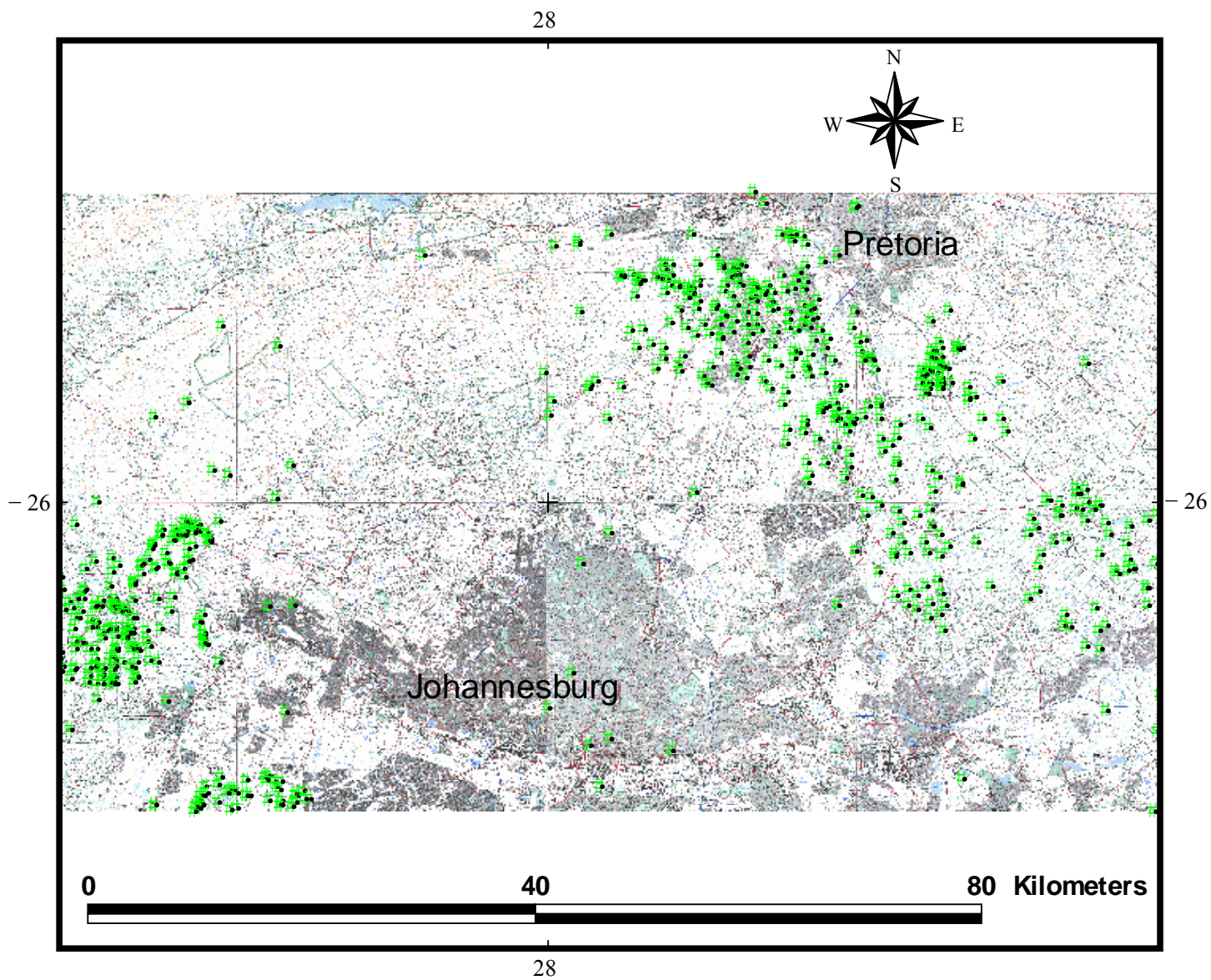

Figure 4. Location map for some water supply wells around Johannesburg.

of karst structures.

From 722 borehole data obtained from DWEA, Pretoria, it was possible to observe variation in borehole yield. The data have been interpreted in such a way that poorly drained crystalline aquifers produce from $0.01 \mathrm{~L} / \mathrm{s}$ to $0.98 \mathrm{~L} / \mathrm{s}$, while weathered and fractured aquifers produce between $1 \mathrm{~L} / \mathrm{s}$ and $14.6 \mathrm{~L} / \mathrm{s}$. High discharge wells are tapping groundwater from dolomites with the rate that varies between $15 \mathrm{~L} / \mathrm{s}$ and $124 \mathrm{~L} / \mathrm{s}$ (DWEA database).

\section{Results and Discussion}

\subsection{Physico-Chemical and Analytical Data}

To assess the hydgeochemical variation in the study area, different combinations of parameters have been plotted and some selected data have been presented in Tables 1 and 2. The distribution of water points (sampling points) is presented in Figure 4. The plots depict one prominent cluster which represent dominant aquifer in the area and dispersed points with high salinity that is related to pollution from gold mining areas. In different aquifers, groundwater contains high salinity due to leaching from weathering profile and pollution derived from gold mines. For the selected boreholes, the distribution of ions with depth has been presented in Figure 5 and the plots portray a relatively decreasing pattern with depth, which, instead, suggests diffusive circulation process due to calcite precipitation within fractures (Figure 5(a)). It is supported by the increasing $\mathrm{pH}$ (Figure 5(b)) due to carbonate saturation.

The increase in $\mathrm{pH}$ with depth (Figure 5(b)) enhances loss of calcium through precipitation process [8] and possible cation exchange with sodium. The lower $\mathrm{pH}$ values at shallow circulation zones could be facilitated by the presence of pollution from mines. In low or no flow condition, dissolved salts move mainly by diffusive rather than advective processes. The diffusive circulation could be attributed to the fracture sealing by precipitated calcite that reduces the available pore space at depth. At shallow depth the presence of relatively less alkaline water could be due to the influence of atmospheric and biogenic carbon dioxide through open fractures and dissolution cavities besides the pollution derived from acid mine decant. The decrease in the concentration of magnesium with depth (Figure 5(c)) reflects less solu- 


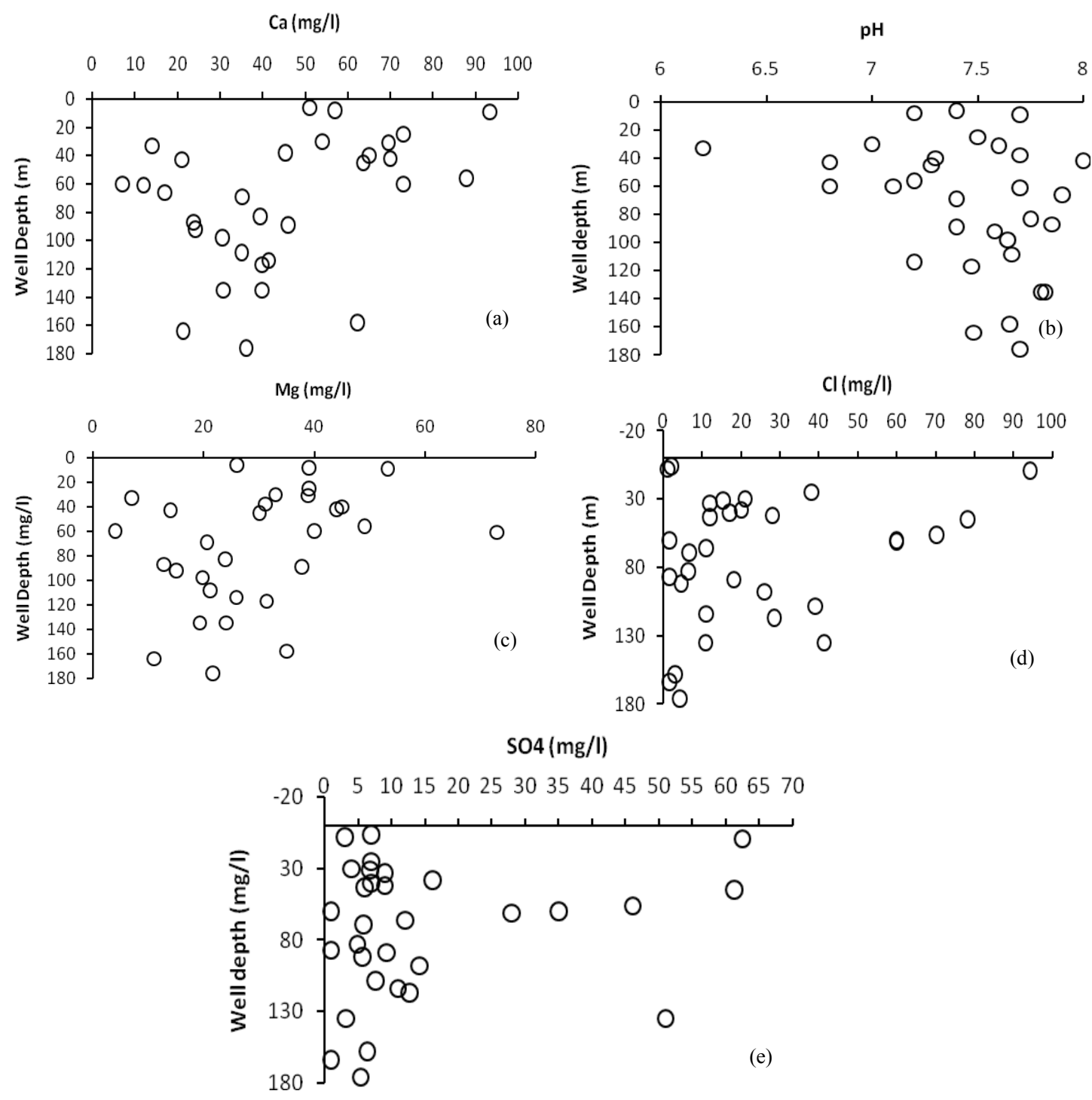

Figure 5. Distribution pattern of chemical constituent with the total well depth.

ble nature of dolomite with chert intercalation that results diffusive movement of ions in the dolomitic aquifer. High concentration of chloride and sulphate are evident, up to the depth of $60 \mathrm{~m}$, likely due to the impact of pollution from mines (Figures 5(d) and 5(e)). Chloride could be added to the aquifer from soluble salts from the weathered profile, rock water interaction (including reaction with matrix minerals, fracture-filling minerals) and the presence of soluble salts.

To evaluate the control pattern of various ions on EC, which has intimate relation with salinity, 2D variation diagrams have been prepared (Figures 6(a) to (d)). The plots show the presence of one dominant cluster (left lower corner) that has low salinity water and the other with highly conductive polluted water at the top right part of the graphs which are related to water from gold mining areas. On same diagrams one can observe the fast enrichment of ions which is related to rock dominance phase with an additional source from multilayer aquifer system or mineral leaching. An interesting observation is evident regarding the fast increase of silica which is believed to be related to silicate dissolution from chert-rich dolomites and granites in more acidic and oxic conditions, which could be assisted by widespread Acid Mine Drainage (AMD) process in the area. The pattern on Figure 6, in general, indicates similar source through weathering of different rock types and mixing of different water types is also a possible controlling process for linear behavior of different water types. The distribution of points on the variation diagrams indicates the importance of all ions at low EC condition (lower left part). The points that lie in right top 


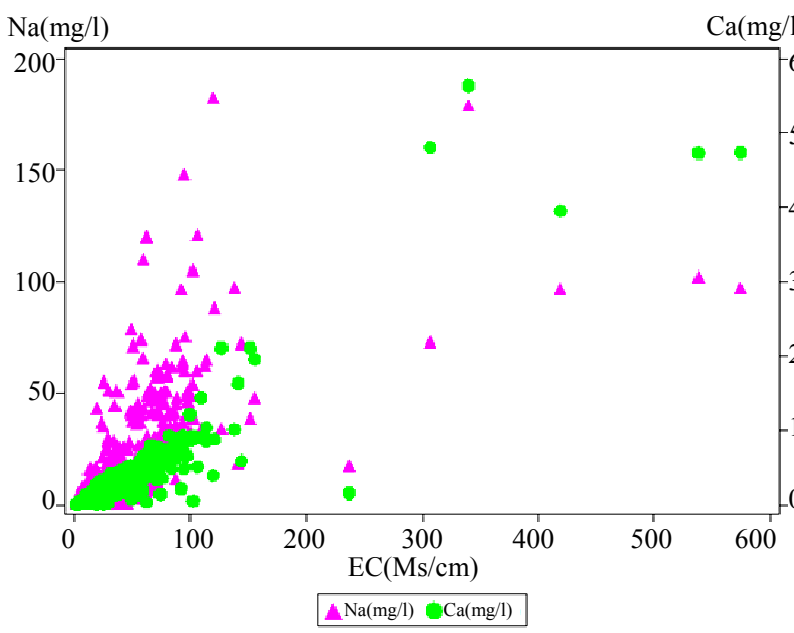

(a)

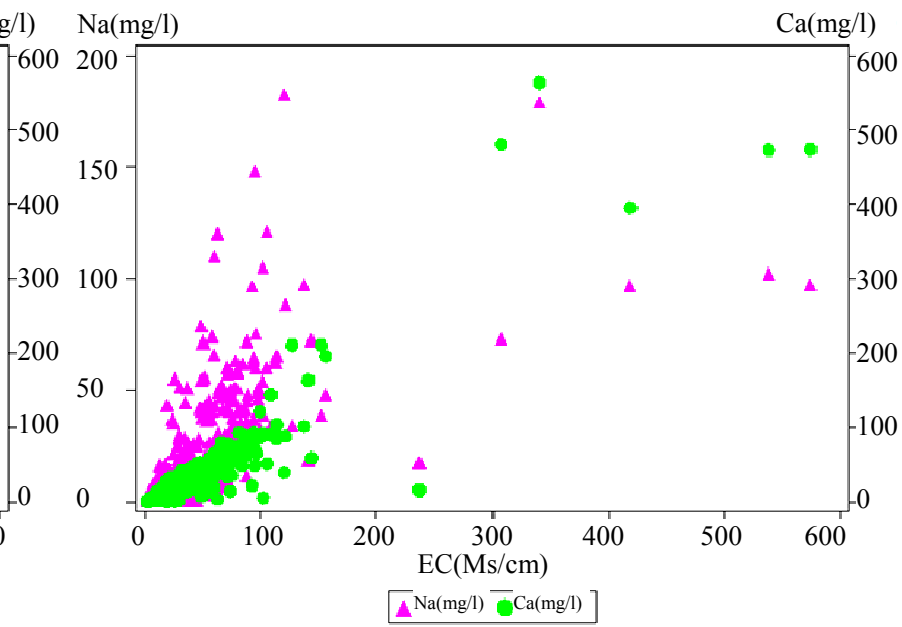

(b)

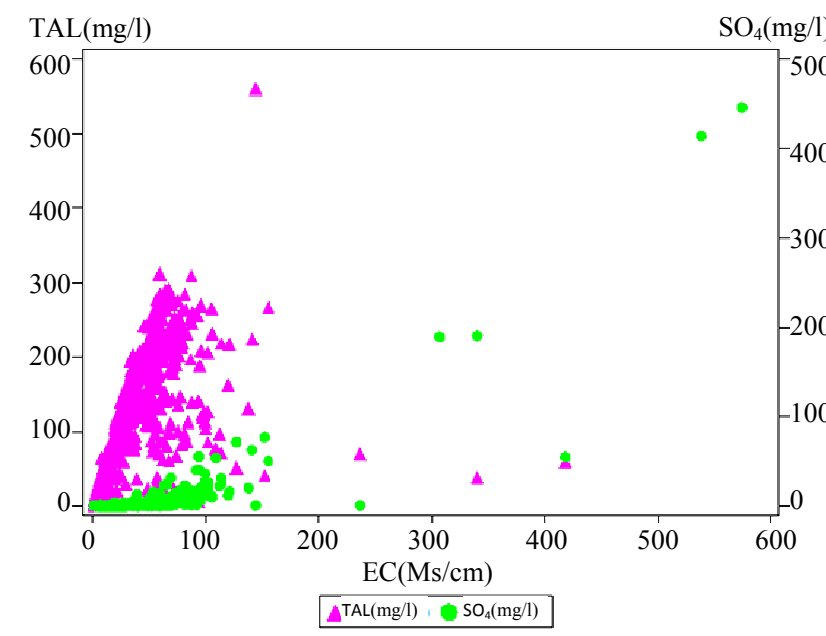

(c)

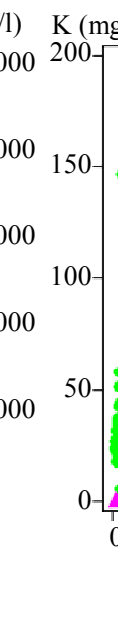

Figure 6. Control pattern of different ions over Electrical conductivity.

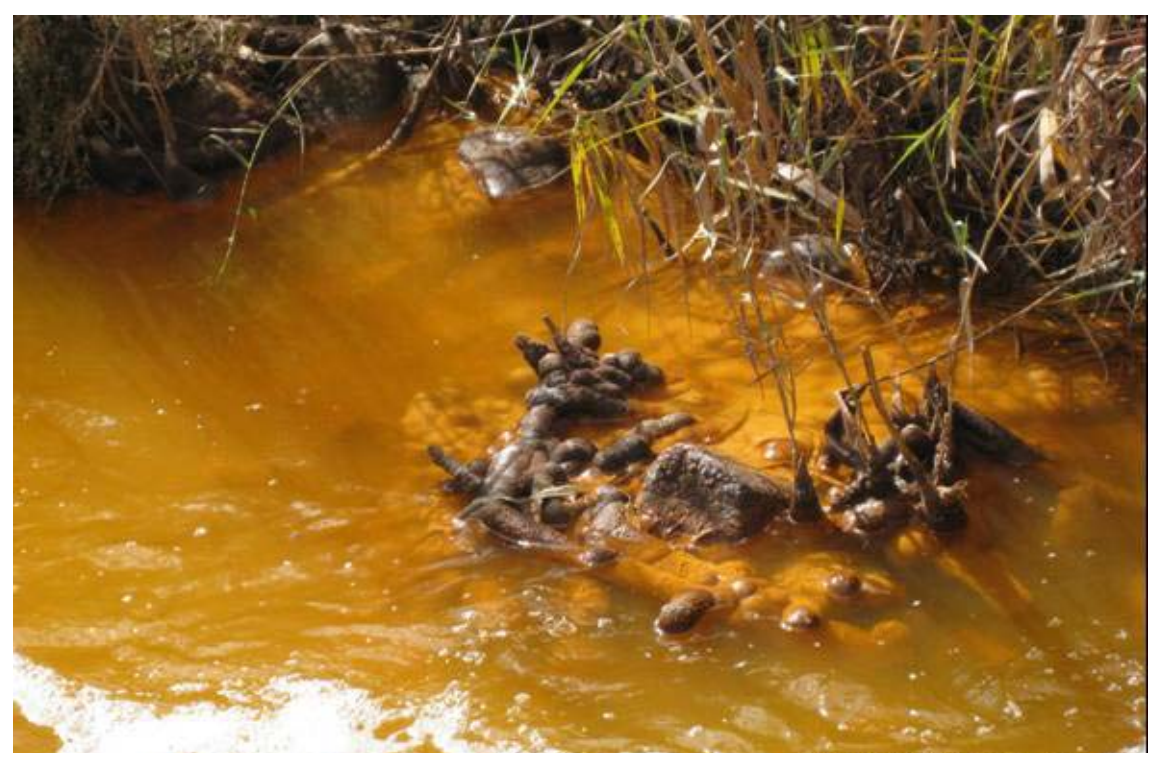

Figure 7. Acid mine decant pictured from one of the streams in the west rand gold mine areas. 
Table 2. Concentration of total iron and sulphate in the groundwater which is affected by acid mine drainage.

\begin{tabular}{|c|c|c|c|c|}
\hline $\begin{array}{c}\text { Sample } \\
\text { code }\end{array}$ & Latitude & Longitude & $\mathrm{SO}_{4} \mathrm{mg} / \mathrm{l}$ & $\begin{array}{c}\mathrm{Fe} \text { (tol) } \\
\mathrm{mg} / \mathrm{l}\end{array}$ \\
\hline W2 & -26.1081 & 27.72278 & 3238.15 & 563.01 \\
\hline W3 & -26.1081 & 27.72278 & 1194.37 & 231.77 \\
\hline W4 & -26.1081 & 27.72278 & 1194.37 & 69.375 \\
\hline W5 & -26.1081 & 27.72278 & 2620.67 & 132.78 \\
\hline W6 & -26.1081 & 27.72278 & 2692.11 & 361.8 \\
\hline W9 & -26.1081 & 27.72278 & 2372.03 & 1179 \\
\hline W10 & -26.1081 & 27.72278 & 2560.66 & 890.4 \\
\hline W14 & -26.1081 & 27.72278 & 2629.64 & 14.313 \\
\hline W15 & -26.1081 & 27.72278 & 2505.04 & 102.1 \\
\hline W16 & -26.1081 & 27.72278 & 2294.46 & 132 \\
\hline W18 & -26.1136 & 27.72278 & 4470.65 & 498.08 \\
\hline W19 & -26.1136 & 27.72278 & 4514.29 & 516.49 \\
\hline W21 & -26.1136 & 27.72278 & 4423.07 & 579.24 \\
\hline W22 & -26.1136 & 27.72278 & 2390.39 & 732.46 \\
\hline W23 & -26.1136 & 27.72278 & 4592.93 & 884.71 \\
\hline W24 & -26.1136 & 27.72278 & 4546.96 & 720 \\
\hline W26 & -26.1136 & 27.72278 & 4512.53 & 279.28 \\
\hline W27 & -26.1136 & 27.72278 & 3502.78 & 503 \\
\hline W28 & -26.1136 & 27.72278 & 3457.99 & 649 \\
\hline W29 & -26.1136 & 27.72278 & 3621.41 & 369.66 \\
\hline W30 & -26.1136 & 27.72278 & 3810.06 & 270.04 \\
\hline W32 & -26.1136 & 27.72278 & 3677.8 & 51.45 \\
\hline W33 & -26.1136 & 27.72278 & 3567.2 & 335.65 \\
\hline W34 & -26.1136 & 27.72278 & 3318.49 & 568.7 \\
\hline W35 & -26.1136 & 27.72278 & 4144.95 & 783.7 \\
\hline W36 & -26.1136 & 27.72278 & 3914.46 & 659.1 \\
\hline W37 & -26.1136 & 27.72278 & 3710.56 & 627.7 \\
\hline W40 & -26.1133 & 27.72278 & 3709.5 & 519.32 \\
\hline W41 & -26.1133 & 27.72278 & 2953.56 & 369.81 \\
\hline W43 & -26.1133 & 27.72278 & 3917.12 & 362.65 \\
\hline W44 & -26.1133 & 27.72278 & 3878.4 & 329.25 \\
\hline W45 & -26.1133 & 27.72278 & 3324.1 & 342.5 \\
\hline W46 & -26.1133 & 27.72278 & 3116.56 & 467.1 \\
\hline W47 & -26.1133 & 27.72278 & 4974.11 & 294.95 \\
\hline W48 & -26.1133 & 27.72278 & 2778.31 & 341.8 \\
\hline W51 & -26.1133 & 27.72278 & 3186.21 & 230.86 \\
\hline W52 & -26.1133 & 27.72278 & 3087.93 & 551.9 \\
\hline W53 & -26.1133 & 27.72278 & 2961.63 & 492.7 \\
\hline W55 & -26.1153 & 27.725 & 4176.01 & 83.69 \\
\hline W58 & -26.1153 & 27.725 & 2644.78 & 986.8 \\
\hline
\end{tabular}

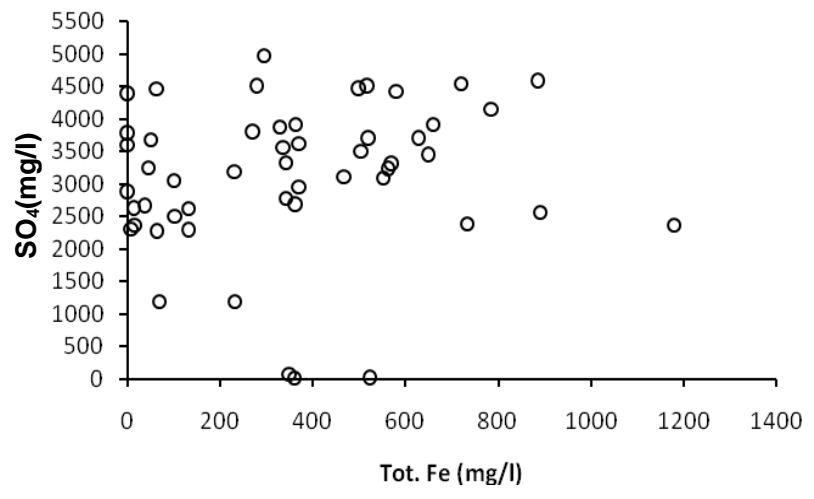

Figure 8. The distribution of Total Iron and SO4 within the boreholes in Johannesburg gold mine area.

part of Figure 6 are related to AMD impact in the shallow boreholes.

Total Alkalinity (TAL) increases rapidly (Figure 6(c)) at an initial stage indicating the presence of multiple sources (carbonate weathering and $\mathrm{CO}_{2}$ reaction in the soil). The influence of atmospheric and soil $\mathrm{CO}_{2}$ probably accounts for increase in TAL values primarily in shallow aquifer. Due to calcite precipitation with depth, TAL is expected to decrease further below $200 \mathrm{~m}$ depth. Similar enrichment patterns of ions indicate mixing of different water and can be considered as an important process to generate these ions.

The impact of Acid Mine Drainage (AMD) is the most dominant environmental problem in the area due to its capacity to dissolve carbonates and direct outflow from mine shafts into the streams as pink coloured flow (Figure 7) with high concentration of total iron and sulphate (Table 2 and Figure 8). The data presented in Table 1 confirm that the groundwater system is influenced by AMD which facilitates mineral dissolution process dominantly in the shallow aquifer system.

\subsection{Principal Component Analyisis}

Principal Component Analysis (PCA) a statistical tool used to descriminate common catagories out of a data cluster to draw sensible and logical conclusion. In previous investigations, PCA was commonly applied for discriminating different water groups in various parts of the world such as in [26,28-30], etc. Therefore, in the current work PCA is used to identify chemistry of dominant groundwater types thereby identifying common geochemical categories and grouping of water quality types besides the interrelations to the aquifer can be done. For the PCA, seven dominant ions/paramters were considered; namely $\mathrm{Ca}, \mathrm{Mg}, \mathrm{Na}, \mathrm{K}, \mathrm{Cl}, \mathrm{SO}_{4}$, and $\mathrm{HCO}_{3}$. It is evident from the data that five principal components (PCs) account for $98.993 \%$ of the total variablity in the data set (Table 3). The loadings are the 


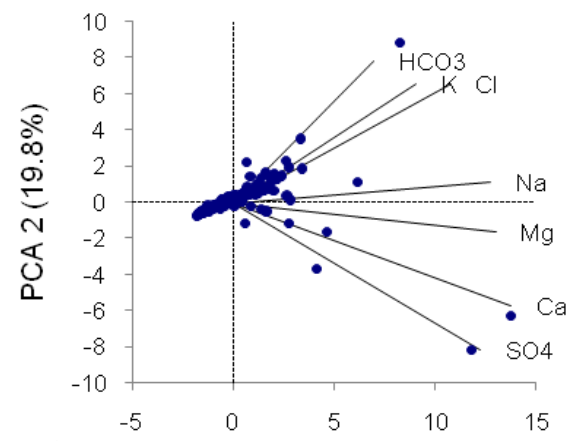

a)

PCA $1(53.4 \%)$

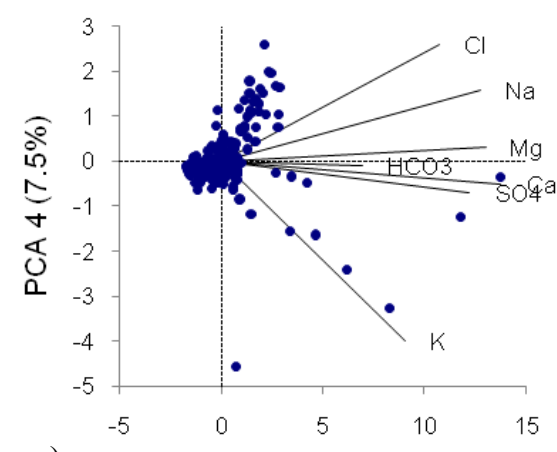

c)

PCA 1 (53.4\%)

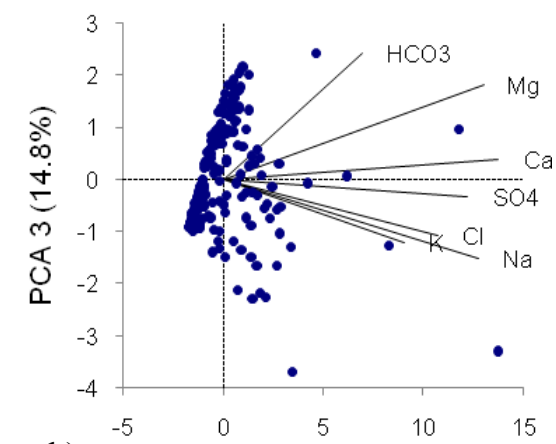

b)

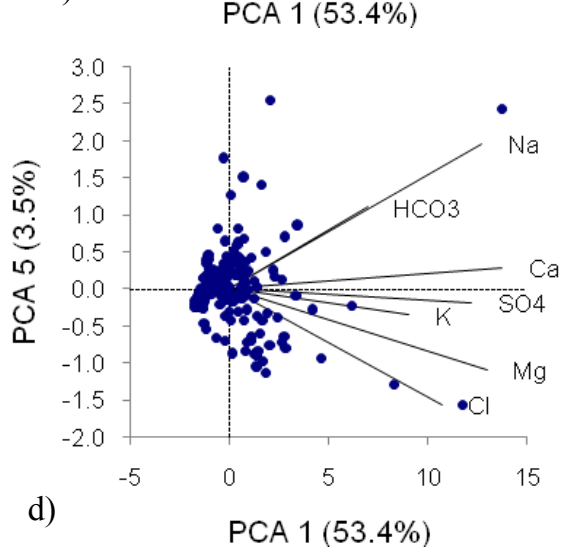

Figure 9. Loading plots of component 2 to 5 on component 1of the groundwater quality a) shallow zone aquifer in the recharge area made of shale, quartizites b) dolomitic aquifer, c) acidic crystalline rocks aquifer such as granite and gneisses, d) weathered zone aquifer in low altitude areas).

Table 3. Weights of the five principal components.

\begin{tabular}{cccccc}
\hline Variable & PC_1 & PC_2 & PC_3 & PC_4 & PC_5 \\
\hline $\mathbf{C a}$ & 0.878 & -0.426 & 0.102 & -0.071 & 0.047 \\
$\mathbf{M g}$ & 0.831 & -0.119 & 0.489 & 0.045 & -0.181 \\
$\mathbf{N a}$ & 0.814 & 0.085 & -0.408 & 0.225 & 0.325 \\
$\mathbf{K}$ & 0.577 & 0.488 & -0.323 & -0.565 & -0.058 \\
$\mathbf{C l}$ & 0.687 & 0.489 & -0.287 & 0.367 & -0.260 \\
$\mathbf{S O}_{4}$ & 0.781 & -0.605 & -0.089 & -0.099 & -0.032 \\
$\mathbf{H C O}_{3}$ & 0.444 & 0.583 & 0.653 & -0.014 & 0.183 \\
eigenvalues & 3.737 & 1.387 & 1.037 & 0.523 & 0.246 \\
Cum. \% & 53.387 & 73.200 & 88.019 & 95.485 & 98.993 \\
\hline
\end{tabular}

correlations between the original variable and the individual components. The values indicate roughly the relative contribution/importance of each variable in each principal component [31]. The result shows that $\mathrm{Ca}, \mathrm{Mg}$, $\mathrm{Na}$ and $\mathrm{SO}_{4}$ have maximum loading on $\mathrm{PC}_{-} 1$, which could be considred as a principal chemical cosntituent of the aquifer in the area except $\mathrm{SO}_{4}$, which is derived from AMD, while $\mathrm{HCO}_{3}$ has highest loading on PC_2 and PC_3.

The clustering of most of the data points to the origin shows significantly dissimilar data. Figure 9(a) shows loading of $\mathrm{PC}_{-} 2$ on $\mathrm{PC}_{-} 1$ with $\mathrm{HCO}_{3}, \mathrm{~K}$ and $\mathrm{Cl}$. Possible occurrence could be shallow groundwater with a source from a shale dominated recharge zone, which is the main lithology on the northeren slope of the watershed. Figure 9(b) shows loading of PC_3 on PC_1 with $\mathrm{HCO}_{3}, \mathrm{Mg}$ and $\mathrm{Ca}$. Possible source is likely to $\bar{b}$ e dolomitic rocks. Figure 9(c) shows loading of PC_4 on PC_ 1 with $\mathrm{Cl}, \mathrm{Na}$ and $\mathrm{Mg}$. For such type of source rock is deducted to be an aquifer of acidic crystalline rock such as granite and gneiss. However, $\mathrm{Cl}$ can be generated from marine precipitarion, urban pollution etc. Figure 9(d) shows loading of PC_5 on PC_1 with $\mathrm{Na}$ and $\mathrm{HCO}_{3}$ which represents particularly shallow circulating groundwater within the weathered zones rich in clay.

\subsection{Environmental Isotope Data}

Environmental isotopes such as $\delta^{18} \mathrm{O}, \delta^{2} \mathrm{H}$ and ${ }^{3} \mathrm{H}$ are widely used to gain some insight into the subsurface flow and recharge condition. These isotopes have been used to study the recharge condition in the sedimentary sequence in South Africa [32,33] to characterize the recharge mechanism and geochemical processes in the arid environment. The plots on Figure 10 indicate that 
Table 4. Environmental isotopes in the Johannesburg area.

\begin{tabular}{|c|c|c|c|c|c|c|c|c|c|c|c|}
\hline Sample code & E (UTM) & N (UTM) & $\mathrm{T}\left({ }^{\circ} \mathrm{C}\right)$ & pH & TDS (mg/L) & $\mathrm{EC}(\boldsymbol{\mu S} / \mathbf{c m})$ & Eh (mv) & $\delta^{18} \mathrm{O}(\% \mathrm{)})$ & $\delta^{2} H(\%)$ & \multicolumn{2}{|c|}{ Tritium (T.U.) } \\
\hline SP1 & 7134258 & 579896 & 22.25 & 7.51 & 116.2 & 181.4 & -15.7 & -5.17 & -29.0 & 2.9 & \pm 0.3 \\
\hline SP2 & 7134851 & 579772 & 22.45 & 8.47 & 120.7 & 188.9 & -64.5 & -4.75 & -27.3 & 3.2 & \pm 0.3 \\
\hline SP3 & 7137898 & 578656 & 22.20 & 7.65 & 140.2 & 220.0 & -22.2 & -5.42 & -31.0 & 0.6 & \pm 0.2 \\
\hline SP4 & 7137903 & 578704 & 21.75 & 7.77 & 145.5 & 228.0 & -29.5 & -5.40 & -31.2 & 1.2 & \pm 0.2 \\
\hline SP5 & 7137958 & 578194 & 21.65 & 8.53 & 110.6 & 172.6 & -73.2 & -5.39 & -30.4 & 1.6 & \pm 0.3 \\
\hline SP6 & 7137953 & 578184 & 20.95 & 8.59 & 87.4 & 136.5 & -75.2 & -5.23 & -30.1 & 2.0 & \pm 0.3 \\
\hline SP7 & 7137893 & 578150 & 21.20 & 8.52 & 77.8 & 121.4 & -76.5 & -5.11 & -29.6 & 1.9 & \pm 0.3 \\
\hline SP8 & 7137885 & 578140 & 23.00 & 8.38 & 108.1 & 168.9 & -63.1 & -5.17 & -29.2 & 2.6 & \pm 0.3 \\
\hline SP9 & 7137818 & 578117 & 21.40 & 7.66 & 110.0 & 172.3 & -31 & -5.64 & -32.4 & 0.2 & \pm 0.2 \\
\hline S1 & 574686 & 7114806 & 20.20 & 7.52 & 118.8 & 185.3 & -0.1 & -2.92 & -13.7 & 3.8 & \pm 0.3 \\
\hline S2 & 572242 & 7112068 & 20.20 & 3.55 & 1502.0 & 2350.0 & 198.1 & -2.56 & -13 & 1.8 & \pm 0.3 \\
\hline S3 & 572107 & 7119673 & 22.10 & 7.53 & 216.0 & 337.0 & -18.2 & -2.22 & -10.7 & 4.6 & \pm 0.4 \\
\hline S4 & 571951 & 7121518 & 21.30 & 7.57 & 217.0 & 339.0 & -21.9 & -2.09 & -9.8 & 4.1 & \pm 0.4 \\
\hline S5 & 577604 & 7124265 & 20.60 & 7.82 & 225.0 & 352.0 & -35.3 & -2.52 & -13 & 2.7 & \pm 0.3 \\
\hline S6 & 577604 & 7124265 & 20.60 & 7.90 & 194.3 & 303.0 & -38.1 & -2.61 & -12.9 & 3.3 & \pm 0.3 \\
\hline S7 & 574187 & 7123145 & 20.50 & 7.82 & 229.0 & 358.0 & -25.4 & -2.28 & -11.2 & 3.5 & \pm 0.3 \\
\hline S8 & 598990 & 7106948 & 21.10 & 8.12 & 135.8 & 212.0 & -48.9 & -2.83 & -12.9 & 5.3 & \pm 0.4 \\
\hline S9 & 600335 & 7107863 & 21.40 & 8.24 & 112.6 & 176.0 & -39.8 & -2.64 & -11.2 & 4.5 & \pm 0.4 \\
\hline P1 & 7103843 & 598632 & 15.40 & 7.44 & 171.9 & 269.0 & -32.6 & -3.08 & -15.0 & 3.9 & \pm 0.3 \\
\hline $\mathrm{P} 2$ & 7106029 & 599933 & 13.20 & 7.20 & 106.0 & 167.0 & -15 & -2.72 & -12.8 & 5.1 & \pm 0.4 \\
\hline P3 & 7111252 & 601923 & 11.20 & 7.99 & 149.1 & 233.0 & -40.5 & -2.35 & -10.7 & 5.2 & \pm 0.4 \\
\hline P4 & 7146708 & 589660 & 16.80 & 8.21 & 181.4 & 284.0 & -52 & -1.53 & -6.0 & 6.6 & \pm 0.4 \\
\hline P5 & 7150413 & 580760 & 20.40 & 9.60 & 146.4 & 229.0 & -125.1 & -1.93 & -9.6 & 15.2 & \pm 0.7 \\
\hline P6 & 7155277 & 584190 & 21.20 & 9.37 & 148.9 & 232.0 & -111.5 & -2.09 & -10.1 & 16.4 & \pm 0.7 \\
\hline P7 & 7160697 & 579527 & 20.40 & 8.84 & 158.1 & 247.0 & -87.7 & -2.18 & -10.4 & 16.7 & \pm 0.7 \\
\hline P8 & 7132300 & 622947 & 18.70 & 7.88 & 210.0 & 328.0 & -39.9 & -1.10 & -3.1 & 4.5 & \pm 0.4 \\
\hline
\end{tabular}




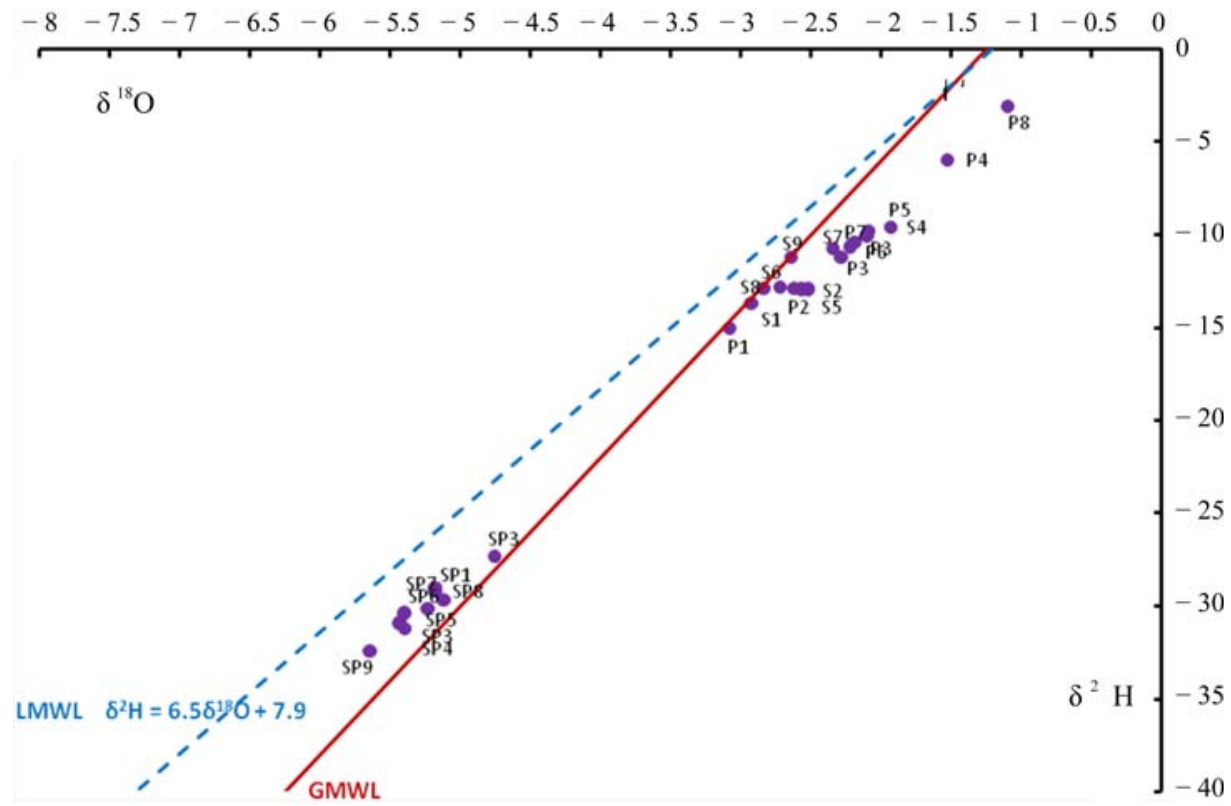

(a)

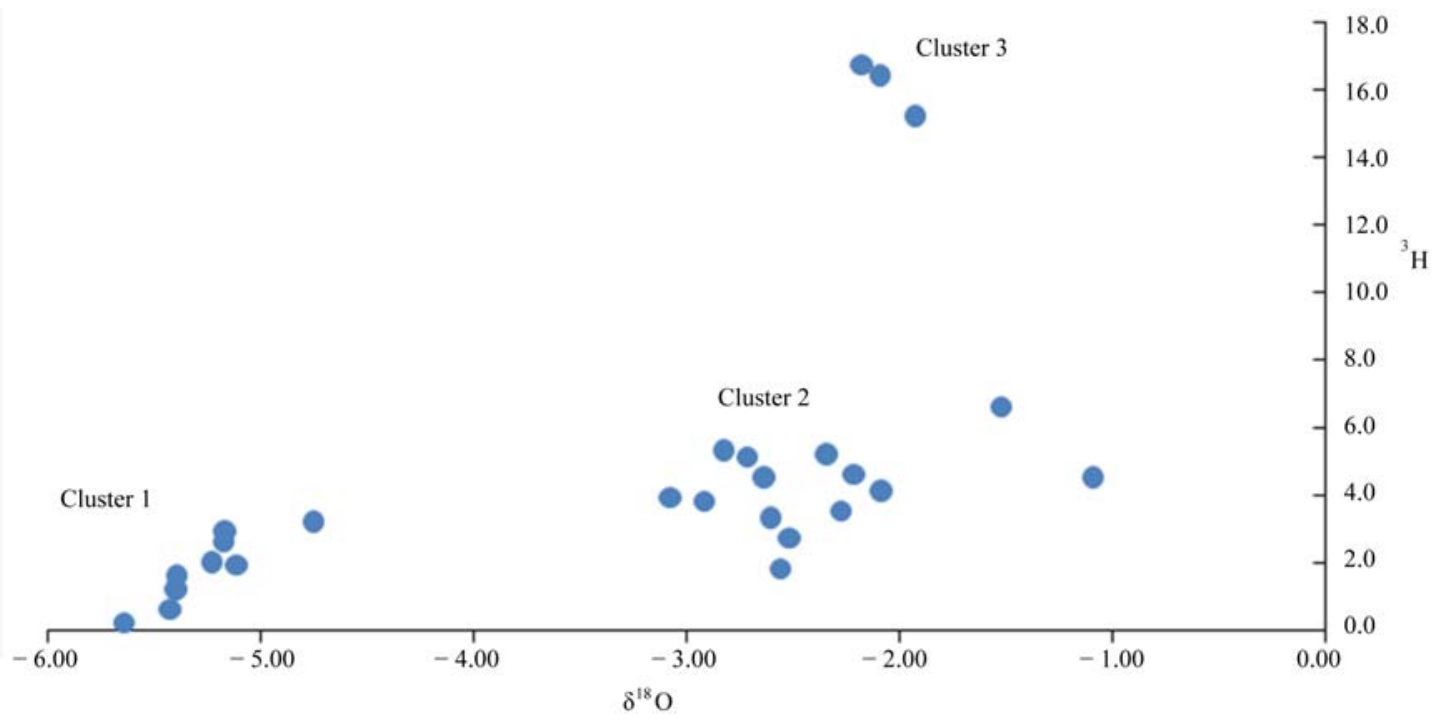

(b)

Figure 10. Environmental isotope distribution in the study area.

there are different aquifers in the area with variable recharge history. All data (Table 4) falling below the Local Meteoric Water Line (LMWL) indicate recharge right after evaporation One of highly productive springs in the Sterkfontein area within the Cradle of Human Kind World Heritage Site, identified as Ngosi spring, emerges as a group of springs from dissolution cavities with a discharge of about $145 \mathrm{~L} / \mathrm{s}$. For this particular spring the measured $\delta^{18} \mathrm{O}, \delta^{2} \mathrm{H}$ and ${ }^{3} \mathrm{H}$ values are $-5.42 \%$, $31.0 \%, 0.6 \pm 0.2 \mathrm{TU}$ respectively. The data show that the spring contains an old water with more than five decades in circulation (low ${ }^{3} \mathrm{H}$ ) and high altitude recharge or deep circulation (depleted stable isotopes) indicating the presence of some deeper circulation chamber in the dolomitic aquifer.

Stable isotope plot with respect to meteoric water lines (Figure 10(a)) portrays two clusters with deep circulation (Cluster 1) within the dolomitic aquifer, slower moving older component of groundwater (depleted $\delta^{18} \mathrm{O}$ and low ${ }^{3} \mathrm{H}$ ), and the shallow circulation within the wea- 
thered crystalline rocks besides streams recharge by interflows (cluster 2). The variation diagrams are found to be supportive of the occurrence of a dominantly shallow groundwater circulation. Figure 8(b) reveals three clusters with the third cluster (cluster 3 ) most likely originating from industrial waste input of the South African Nuclear Energy Corporation whereas the remaining two clusters conform to the shallow circulation.

\section{Conclusions}

The extreme precarious geoenvironmental setting of the greater Johannesburg area highly impacted the groundwater resource where the influence of the lithology and pollution on the water composition is manifested through the variation in the groundwater quality. The study revealed the loss of major ions with depth in the crystalline aquifers of the study area showing the main movement mechanism of chemical constituents is diffusive type, which suggests the decrease in water velocity with depth. It is highly likely that diffusive circulation is caused by fracture sealing by calcite precipitation that reduces the available permeability with depth. The enhanced dissolution of minerals due to acid mine drainage has important contribution for the evolution of ions in the groundwater. Rapid infiltration through fractures or dissolution cavities results in low degree of water-rock interaction and hence, low salinity waters exist within the dolomitic aquifer with low chloride and depleted $\delta^{18} \mathrm{O}$, indicating recharge from relatively high altitude. It was observed that slow moving older groundwater (depleted $\delta{ }^{18} \mathrm{O}$ and low ${ }^{3} \mathrm{H}$ ) occurs within the weathered crystalline aquifer and it mixes with relatively young and shallow moving locally recharged water.

\section{Acknowledgements}

The authors are very grateful to the Department of Water and Environmental Affairs (DWEA) of South Africa for providing the relevant groundwater quality data. T. Abiye acknowledges the financial support of the National Research Foundation (NRF) and Water Research Commission (WRC) of South Africa for additional sampling of environmental isotopes.

\section{References}

[1] M. S. Basson and J. A. Van Rooven, "Tunneling into the Future: The Role of Water Resources Development in South Africa," Tunnelling and Underground Space Technology, Vol. 13, No. 1, 1998, pp. 35-38. doi:10.1016/S0886-7798(98)00019-4

[2] F. S. Botha and J. L. Van Rooy, "Affordable Water Resource Development in the Northern Province," African
Earth Sciences, South Africa, Vol. 33, 2001, pp 687-692.

[3] D. B. Bredenkamp, C. Van der Westhuizen, F. E. Wiegmans and C. Kuhn, "Groundwater Supply Potential of Dolomite Compartments West of Krugersdorp," Directorate of Geohydrology, DWAF1986., Report No. GH 3440. Pretoria, South Africa.

[4] D. B. Buttrick, J. L. VAN Root and R. Ligthelm, "Environmental Geological Aspects of the Dolomites of South Africa," Journal of African Earth Sciences, Vol. 16, 1993, pp. 53-61. doi:10.1016/0899-5362(93)90161-I

[5] D. B. Bredenkamp and Y. Xu, "Perspectives on Recharge Estimation in Dolomitic Aquifers in South Africa," In: Y. Xu and H. F. Beekman, Eds., Groundwater Recharge Estimation in Southern Africa, UNESCO, 2003, p. 207.

[6] DWAF (Department of Water Affairs and Forestry), "Hydrology of Upper Crocodile River Sub-System," Report No. PA200/00/1492, Vol. 1-2, DWAF 1992, Pretoria, South Africa.

[7] P. G. Cook, A. J. Love, N. I. Robinson and C. T. Simmons, "Groundwater Ages in Fractured Rock Aquifers," Journal of Hydrology, 2005, Vol. 308, pp. 284-301. doi:10.1016/j.jhydrol.2004.11.005

[8] M. Gascoyne, "Hydrogeochemistry, Groundwater Ages and Sources of Salts in a Granitic Batholiths on the Canadian Shield, Southern Manitoba," Applied Geochemistry, 2004, Vol. 19, No. 4, pp. 519-560. doi:10.1016/S0883-2927(03)00155-0

[9] I. Stober and K. Bucher, "Deep Groundwater in the Crystalline Basement of the Black Forest Region," Applied Geochemistry, Vol. 14, No. 2, 1999, pp. 237-254. doi:10.1016/S0883-2927(98)00045-6

[10] H. C. Barnard, "An Explanation for the 1:500 $000 \mathrm{Hy}-$ drogeological Map of Johannesburg 2526," Department of Water Affairs and Forestry, Pretoria, Johannesburg, RSA, 2000.

[11] Ferret Report, "Derivation of a Numerical Model for a Cumulative Water Balance of the Central Rand Basin," Council for Geosciences, Pretoria, South Africa, 2005.

[12] Africa Geo-Environmental Services (AGES) Report, "Numerical Modeling of Seepage Potential at Three Ingress Areas of the Central Rand Basin of the Witwatersrand Goldfields," Council for Geosciences, Pretoria, South Africa, 2005.

[13] K. T. Witthüser and M. Holland, "Hydrogeology of the Cradle of Humankind World Heritage Site, South Africa," The 12th International Conference of International Association for Computer Methods and Advances in Geomechanics (IACMAG), 1-6 October, 2008, Goa, India.

[14] H. Coetzee, E. Chirenje, P. Hobbs and J. Cole, "Ground and Airborne Geophysical Surveys Identify Potential Subsurface Acid Mine Drainage Pathways in the Krugersdorp Game Reserve, Gauteng Province, South Africa," Proceedings of the 11th SAGA Meeting and Exhibition, Swaziland, 16-18 September 2009, pp. 461-470.

[15] P. J. Hobbs and J. E. Cobbing, "A Hydrogeological Assessment of Acid Mine Drainage Impacts in the West 
Rand Basin," Report No. CSIR/THRIP, Gauteng Province, South Africa, 2007.

[16] M. Poujol and C. R. Anhaeusser, "The Johannesburg Dome, South Africa: New Single Zircon U-Pb Isotopic Evidence for Early Arcahean Granite-Greenstone Development within the Central Kaapvaal Craton," Precambrian Research 2001, Vol. 108, pp. 139-157. doi:10.1016/S0301-9268(00)00161-3

[17] E. S. Barton, W. Compston, I. S. Williams, J. W. Bristow, D. K. Hallbauer and C. B. Smith, "Provenance Ages for the Witwatersrand Supergroup and the Ventersdorp Contact Reef: Constraints from Ion-Microprobe U-Pb Ages of Detrital Zircons," Economic Geology, Vol. 84, 1989, pp. 2012-2019. doi:10.2113/gsecongeo.84.7.2012

[18] R. A. Armstrong, W. Compston, E. A. Retief, L. S. William and H. J. Welke, "Zircon Ion Microprobe Studies Bearing on the Age and Evolution of the Witwatersrand triad," Precambrian Research, Vol. 53, 1991, pp. 243266. doi:10.1016/0301-9268(91)90074-K

[19] J. M. Barton, E. S. W. Barton and A. Kroner, "Age and Isotopic Evidence for the Origin of the Archaean Granitoid Intrusive of the Johannesburg Dome, South Africa," Journal Afrcan Earth Sciences, Vol. 28, No. 3, 1999, pp 693-702. doi:10.1016/S0899-5362(99)00039-1

[20] R. E. Meyers, T. S., McCarthy and I. G. Stanistreet, “A Tectono-Sedimentary Reconstruction of the Development and Evolution of the Witwatersrand Basin, with Particular Emphasis on the Central rand Group," South African Journal of Geology, Vol. 93, No. 1, 1990, pp. 180-201.

[21] L. J. Robb and F. M. Meyer, "The Witwatersrand Basin, South Africa: Geological Framework and Mineralization Processes," Ore Geology Reviews, Vol. 10, No. 2, 1995, pp. 67-94. doi:10.1016/0169-1368(95)00011-9

[22] T. S. McCarthy, "The Witwatersrand Supergroup," In: C. R. Haeusser, R. J. Thoms and M. R. Johnson, Eds., The Geology of South Africa, 2006, pp. 155-186.

[23] P. G. Eriksson and C. W. Clendenin, "A Review of the Transvaal Sequence, South Africa," Journal of African Earth Sciences, Vol. 10, No. 1-2, 1990, pp. 101-116. doi:10.1016/0899-5362(90)90049-K

[24] P. G. Eriksson, W. Altermann and F. J. Hartzer, "The
Transvaal Supergroup and Its Precursors," In: M. R. Johnson, C. R. Anhaeusser and R. J. Thoms, Eds., The Geology of South Africa, 2006, pp. 237-260.

[25] H. C. Barnard, "Hydrogeological Map of Johannesburg 2526. 1:500 000 Department of Water Affairs and Forestry," Pretoria, Johannesburg, South Africa, 1999.

[26] M. J. Duane, G. Pigozzi and C. Harris, "Geochemistry of Some Deep Gold Mine Waters from the Western Portion of the Witwatersrand Basin, South Africa," Journal of African Earth Sciences, 1997, Vol. 24, No. 1-2, pp. 105123. doi:10.1016/S0899-5362(97)00030-4

[27] C. R. Anhaeusser, "Ultramafic and Mafic Intrusions of the Kaapvaal Craton," In: M. R. Johnson, C. R. Anhaeusser, R. J. Tomas, Eds., The Geology of South Africa, Council for Geosciences, 2006, pp. 95-134.

[28] K. Barnes, W. Ellery and A. Kindness, "A Preliminary Analysis of Water Chemistry of the Mkuze Wetland System, KwaZulu-Natal: A Mass Balance Approach," WaterSA, Vol. 28, No. 1, 2001, pp. 1-12.

[29] B. O'Shea and J. Jankowski, "Detecting Subtle HydroGeochemical Anomalies with Multivariable Statistics: An Example from 'Homogenous' Groundwater in the Great Artesian Basin, Australia," Hydrological Processes, Vol. 20, 2006, pp. 4317-4333.

[30] D. Dong, Q. Wu, R. Zhang, Y. Song, S. Chen, P. Li, S. Liu, C. Bi, Z. Lv and S. Huang, "Environmental Characteristics of the Groundwater: An Application of PCA to Water Chemistry Analysis in Yulin," Journal of China University Mining and Technology, Vol. 17, No. 1, 2007, pp. 0073-0077.

[31] X. L. Statisti, "Statistixl 1.5, Broadwa-Nedlands, Western Australia," 2005. http://www.statistixl.com

[32] K. Sami, "Recharge Mechanisms and Geochemical Processes in a Semi Arid Sedimentary Basin, Eastern Cape, South Africa," Journal of Hydrology, Vol. 139, 1992, pp. 27-48. doi:10.1016/0022-1694(92)90193-Y

[33] S. Adams, R. Titus, K. Pietersen, G. Tredoux and C. Harris, "Hydrochemical Characteristics of Aquifers Near Sutherland in the Western Karoo, South Africa," Journal of Hydrology, Vol. 241, No. 1-2, 2001, pp. 91-103. doi:10.1016/S0022-1694(00)00370-X 